\title{
Molecular authentication of Maytenus sp by PCR-RFLP
}

\section{Autenticação molecular de Maytenus sp por PCR-RFLP}

\author{
Sandra Sayuri Nakamura ${ }^{1}$; Juliana Silveira do Valle²; Ezilda Jacomassi²; \\ Giani Andrea Linde ${ }^{3}$; Nelson Barros Colauto ${ }^{3 *}$
}

\begin{abstract}
Maytenus aquifolia and Maytenus ilicifolia are native plants from South America and popularly known as 'Espinheira-santa'. Both are used as tea due to their efficiency in the treatment of ulcer, gastritis and indigestion. However, adulteration of processed Maytenus genus tea with Sorocea genus may happen due to their botanical similarity, compromising the quality of the products and opening a derogatory business opportunity that may lead to the discrediting of medicinal plant products. This study aimed to distinguish Maytenus sp and Sorocea bonplandii by PCR-RFLP of a chloroplast DNA (cpDNA) intergenic region. Three commercial products of processed tea leaves of Maytenus sp, and in natura leaves of Maytenus sp and S. bonplandii were analyzed. PCR detected unique fragments for all samples in natura. The trnH-psbA region amplicon of both M. ilicifolia and M. aquifolia was $660 \mathrm{bp}$, and for $S$. bonplandii was $565 \mathrm{bp}$. These PCR products can be used as markers to distinguish the two genera. Forty-five percent of the processed samples presented only Maytenus genus, without adulterations. However, the amplification of $38 \%$ of the samples suggests adulteration with $S$. bonplandii while $17 \%$ seem to be adulterated with another plant (fragment of $649 \mathrm{bp}$ in brand A and $690 \mathrm{bp}$ in brand B). Three out of the fifteen restriction enzymes were able to detect M. ilicifolia and M. aquifolia in natura and in processed leaf samples. It was concluded that PCR technique is efficient to distinguish Maytenus sp from S. bonplandii, and other adulterating plants in processed commercial products of 'Espinheira-santa' tea. The $t r n H-p s b A$ spacer of cpDNA is easily amplified and has satisfactory discriminating capacity to help in authentication processes of samples of the genera in natura and in processed plants.
\end{abstract}

Key words: Maytenus aquifolia, Maytenus ilicifolia, Sorocea bonplandii, Celastraceae, Moraceae, trnH-psbA

\section{Resumo}

\begin{abstract}
Maytenus aquifolia e Maytenus ilicifolia são plantas nativas da América do Sul e conhecidas popularmente como "Espinheira-santa". Ambas são usadas como chá devido à sua eficiência no tratamento de gastrite, úlcera e indigestão. No entanto adulteração de chá do gênero Maytenus com o gênero Sorocea pode acontecer devido a sua semelhança botânica e isto compromete a qualidade dos produtos, abrindo uma oportunidade para comércio depreciativo que leva ao descrédito das plantas medicinais. Este estudo teve como objetivo distinguir Maytenus sp e Sorocea bonplandii por PCR-RFLP de DNA da região intergênica do cloroplasto (cpDNA). Três produtos comerciais de chá de Maytenus sp foram analisados, e a análise foi feita também em folhas in natura de Maytenus sp e de $S$. bonplandii. PCR detectou fragmentos únicos para todas as amostras in natura. O amplicon da região trnH-psbA de M. ilicifolia e M. aquifolia foi de $660 \mathrm{pb}$ e para $S$. bonplandii foi de $565 \mathrm{pb}$. Os produtos de PCR podem ser usados
\end{abstract}

\footnotetext{
${ }^{1}$ Farmacêutica, Universidade Paranaense, UNIPAR, Umuarama, PR. E-mail: sahnakamura@gmail.com

${ }^{2}$ Prof $^{\text {s }}$ Dr $^{{ }^{a} \mathrm{~s}}$ Titular, Curso de Farmácia, Laboratório de Biologia Molecular, UNIPAR, Umuarama, PR. E-mail: jsvalle@unipar.br; ezilda@unipar.br

${ }^{3}$ Profs. Drs. Titular, Mestrado em Biotecnologia Aplicada à Agricultura, Laboratório de Biologia Molecular, UNIPAR, Umuarama, PR. E-mail: gianilinde@unipar.br; nbc@unipar.br

${ }^{*}$ Author for correspondence
} 
como marcadores para distinguir os dois gêneros. Quarenta e cinco por cento das amostras processadas apresentaram apenas o gênero Maytenus, sem adulterações. No entanto, a amplificação de $38 \%$ das amostras sugere adulteração com $S$. bonplandii, enquanto $17 \%$ parecem terem sido adulteradas com uma outra planta (fragmento de 649 pb na marca A e 690 pb na marca B). Três das quinze enzimas de restrição foram capazes de detectar M. ilicifolia e M. aquifolia in natura e em amostras de folhas processadas. Concluiu-se que a técnica de PCR é eficiente para distinguir Maytenus sp de S. bonplandii e outras plantas adulterantes nos produtos comerciais de chá de "Espinheira-santa". O espaçador trnH$p s b A$ de cpDNA é facilmente amplificado e tem capacidade discriminante satisfatória para ajudar em processos de autenticação dos gêneros em amostras in natura e processadas de plantas.

Palavras-chave: Maytenus aquifolia, Maytenus ilicifolia, Sorocea bonplandii, Celastraceae, Moraceae, trnH-psbA

\section{Introduction}

Maytenus aquifolia Mart. and Maytenus ilicifolia Mart. ex. Reissek (Celastraceae) are native plants of South America and popularly known as 'Espinheira-santa' (JORGE et al., 2004). Both are used as tea due to their efficiency in the treatment of ulcer, gastritis and indigestion (CARLINI; BRAZ, 1988). The high demand for these medicinal plants has increased their uncontrolled extraction in their natural environment. Although they are well known as Maytenus sp, they are morphologically confused with Sorocea bonplandii (Baill.) W.C.Burger, Lanj. \& Boer (Moraceae), which is also a native plant from the same environment. The adulteration of processed Maytenus tea with Sorocea genus apparently does not harm the consumers' health because $S$. bonplandii has analgesic and antiulcerogenic properties (GONZALEZ et al., 2001; VILEGAS et al., 1998). However, the presence of $S$. bonplandii in 'Espinheira-santa' teas indicates the need of authentication of medicinal plants used in commercial products.

Authentication of medicinal plants by taxonomists or by chemical markers is limited due to the specific knowledge required from the former (NODARI; GUERRA, 1999; SONG et al., 2009) and the lack of trust in the latter that are susceptible to environmental changes (UM et al., 2001; ZHAO et al., 2007). The use of DNA markers in the authentication process can solve some of these problems, as DNA is not susceptible to alteration due to cultivation conditions and can be obtained from a small amount of biological material, even after processed (INFANTE et al., 2006; UJIHARA et al., 2009).

In plants, in general, the mitochondrial genome presents low variability and its utility as molecular marker for identification or authentication of plants products is low (CHASE et al., 2007). However, intergenic regions of chloroplast DNA (cpDNA) have been used successfully to characterize angiosperms (FAZEKAS et al., 2008; HOLLINGSWORTH et al., 2009; LAHAYE et al., 2008; SONG et al., 2009) and it also could be a tool to distinguish Maytenus and Sorocea genera. Moreover, there are no data in literature about the use of DNA markers to distinguish these genera. Thus, due to the absence of studies on the authentication of Maytenus sp by DNA sequences and the importance of the authenticity of plants used as medicine to the sustainable development of the natural product industry, this study aimed to distinguish Maytenus sp from $S$. bonplandii using the trnH-psbA intergenic regions of cpDNA by PCR-RFLP technique to identify a molecular marker between in natura as well as commercially processed Maytenus sp and S. bonplandii.

\section{Material and Methods}

Leaves from six M. aquifolia (Ma), eight $M$. ilicifolia (Mi) and seven $S$. bonplandii $(\mathrm{Sb})$ bushes were harvested at the Medicinal Plant Herbarium of the Universidade Paranaense in Umuarama- 
PR, Brazil. The plants were identified and a voucher specimen of each species was deposited at the Educational Herbarium of the Universidade Paranaense (registration numbers 2063, 2064 and 2065). Each leaf was washed with ethanol $70 \%$ and distilled water and stored at $-70{ }^{\circ} \mathrm{C}$.

Some dried leaf teas of 'Espinheira-santa' (Ma or Mi) were purchased from local traders. They were from three different broadly-commercialized brands that were identified as A, B or C, and four packages of each of them were chosen randomly and coded as 1, 2, 3 or 4 . The total content of each package was washed twice with sodium hypochlorite $1 \%$ for 5 min under agitation and then washed with ultrapure water for $5 \mathrm{~min}$. Next, they were dried at $60^{\circ} \mathrm{C}$ in an air circulation oven for $90 \mathrm{~min}$. After that, it was ground in an analytical grinder, sieved $(1.0 \mathrm{~mm}$ mesh) and stored in glass flasks with silica gel at room temperature $\left(25^{\circ} \mathrm{C}\right)$ in the dark. Each package of processed leaves was analyzed in triplicate and codified as sample I, II or III.

In order to extract genomic DNA (DOYLE; DOYLE, 1987), $4 \mathrm{~cm}^{2}$ of a leaf in natura was used (Ma, Mi or Sb), stored in micro tubes and frozen again for $20 \mathrm{~min}$ at $-70{ }^{\circ} \mathrm{C}$. Then, the material was macerated and extraction buffer was added. The resulting DNA was suspended in TE (1 mM Tris-
$\mathrm{HCl} ; 0.1 \mathrm{mM}$ EDTA $\mathrm{pH}$ 8.0) and kept frozen at $-20{ }^{\circ} \mathrm{C}$. In the analysis of the commercial samples, $5 \mathrm{mg}$ of ground leaves were used according to the previous protocol(DOYLE; DOYLE, 1987) without freezing and maceration. The DNA extractions were done in triplicate, and the DNA concentration and purity degree of each sample were determined by spectrophotometry.

Universal primers described by Cuénoud et al. (2002) (Table 3) were used to amplify the trnH-psbA intergenic spacer regions of cpDNA. Amplification process occurred in a thermo cycler (Mastercycler Gradiente - Eppendorf) programmed for initial denaturation at $94{ }^{\circ} \mathrm{C}$ for $4 \mathrm{~min}$; followed by 35 cycles: denaturation at $94{ }^{\circ} \mathrm{C}$ for $30 \mathrm{~s}$, annealing at $60{ }^{\circ} \mathrm{C}$ for $30 \mathrm{~s}$ and extension at $72{ }^{\circ} \mathrm{C}$ for $30 \mathrm{~s}$, followed by final extension at $72{ }^{\circ} \mathrm{C}$ for $7 \mathrm{~min}$. The final $25 \mu \mathrm{L}$ volume reaction contained DNA (25 ng), $\mathrm{MgCl}_{2}(1.5 \mathrm{mM})$, enzyme buffer (200 mM Tris- $\mathrm{HCl}$ pH 8.4; $500 \mathrm{mM} \mathrm{KCl})$, dNTP $(100 \mu \mathrm{M}$ of each), primer $(0.2 \mu \mathrm{M})$, and Taq DNA polymerase (1.5 $\mathrm{U})$. The amplification products were submitted to electrophoresis in agarose gel at $1 \%$ with ethidium bromide and photographed under ultraviolet light. The amplification reaction was replicated three times.

Table 1. Sequence of primers used in the amplification of trnH-psbA intergenic spacer of chloroplast DNA of Maytenus sp and Sorocea bonplandii.

\begin{tabular}{lc}
\hline Primer & Sequence $\left(\mathbf{5}^{\prime} \rightarrow \mathbf{3}^{\prime}\right)$ \\
\hline trnHf & CGCGCATGGTGGATTCACAATCC \\
$p s b A 3 F$ & GTTATGCATGAACGTAATGCTC \\
\hline
\end{tabular}

Source: Elaboration of the authors.

For leaves in natura, PCR products were digested with 15 restriction endonucleases (AccI, AluI BamHI, EcoRI, HaeIII, HindIII, Hinfl, HhaI, KpnI, MboI, MseI, RsaI, SalI, PstI, PvuII) following the manufacturer's recommendation. The fragments were separated by electrophoresis in agarose gel at $1.5 \%$ with ethidium bromide and photographed under ultraviolet light. The fragment size of PCR products before and after the digestion was estimated in base pairs (bp) by comparing them to 1 $\mathrm{kb}$ plus DNA ladder ${ }^{\circledR}$. Only the enzymes that could cut the amplicons of leaves in natura were used for the amplicons of processed leaves. 


\section{Results and Discussion}

The trnH-psbA intergenic spacer presented enough variation to distinguish the analyzed genera in this study. In Fig. 1, it can be observed that $M$. ilicifolia and M. aquifolia amplifications generated fragments with $660 \mathrm{bp}$, and for S. bonplandii with 565 bp. In literature, different applications of PCR and PCR-RFLP are reported, using nuclear or cpDNA regions in order to distinguish ginseng species (Panax ginseng and Panax quinquefolius) (NGAN et al., 1999) and medicinal species of Hedyotis diffusa and Hedyotis corymbos (LI et al., 2010), in the authentication of the Polygonaceae family in Chinese pharmacopoeia (SONG et al., 2009) and in Actinidia macrosperma (ZHAO et al., 2007). Some of these studies did not obtain results only with PCR, making the PCR-RFLP analysis necessary.

Figure 1. Amplification products of trnh-psbA intergenic spacer of chloroplast DNA from leaves in natura of Maytenus ilicifolia (Mi), Maytenus aquifolia (Ma) and Sorocea bonplandii (Sb). $\mathrm{NC}=$ Negative Control and $\mathrm{P}=1 \mathrm{~kb}$ plus DNA ladder.

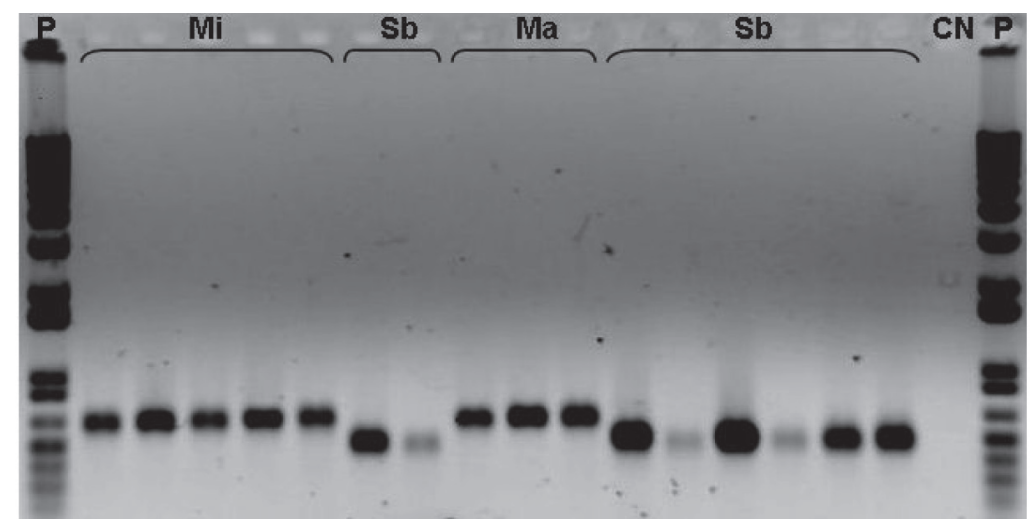

Source: Elaboration of the authors.

Another aspect that reinforces the trustworthiness of the use of this technique to distinguish Maytenus genus from $S$. bonplandii is the high annealing temperature during amplification $\left(60{ }^{\circ} \mathrm{C}\right)$ that guarantees a very specific amplification. Even with the high temperature used during primer annealing, the reactions generated a great number of copies of the target sequence. Thus, it was observed that size polymorphism obtained only with PCR allowed distinguishing Maytenus genus of $S$. bonplandii. These results corroborate the high discriminating power of trnH-psbA cpDNA region, suggesting the possibility of adopting this segment as a marker to distinguish Maytenus genus from its main adulterant, $S$. bonplandii, with the advantage of not using DNA sequencing.

In the analysis of processed leaves (tea) of the Maytenus genus, 20\% of the samples showed no amplification of trnH-psbA (Table 1). The absence of amplification suggests that the DNA was degraded during leaf processing once DNA from in natura leaves of $M$. ilicifolia, $M$. aquifolia and $S$. bonplandii were able to anneal even at specific high amplification temperature $\left(60^{\circ} \mathrm{C}\right)$. 
Table 2. Amplification result of the trnH-psbA region of chloroplast DNA from processed leaves of commercial brands of M. ilicifolia and M. aquifolia known as 'Espinheira-santa', purchased in Umuarama-PR.

\begin{tabular}{|c|c|c|c|c|c|}
\hline \multicolumn{3}{|c|}{ Processed leaves } & \multirow{2}{*}{$\begin{array}{c}\text { Maytenus genus } \\
-\end{array}$} & \multirow{2}{*}{$\frac{\text { Sorocea bonplandii }}{-}$} & \multirow{2}{*}{$\frac{\text { Another genus }}{+}$} \\
\hline \multirow{12}{*}{$\mathbf{A}$} & & I & & & \\
\hline & 1 & II & - & - & + \\
\hline & & III & - & - & + \\
\hline & & I & + & - & - \\
\hline & 2 & II & + & - & - \\
\hline & & III & + & - & - \\
\hline & & I & + & - & - \\
\hline & 3 & II & + & - & - \\
\hline & & III & + & - & - \\
\hline & & I & + & - & - \\
\hline & 4 & II & + & - & - \\
\hline & & III & + & - & - \\
\hline \multirow{12}{*}{ B } & & I & - & - & + \\
\hline & 1 & II & - & - & + \\
\hline & & III & aa & aa & aa \\
\hline & & I & + & - & - \\
\hline & 2 & II & aa & aa & aa \\
\hline & & III & aa & aa & aa \\
\hline & & I & aa & aa & aa \\
\hline & 3 & II & aa & aa & aa \\
\hline & & III & aa & aa & aa \\
\hline & & I & + & - & - \\
\hline & 4 & II & + & - & - \\
\hline & & III & + & - & - \\
\hline \multirow{12}{*}{ C } & & I & + & + & - \\
\hline & 1 & II & + & + & - \\
\hline & & III & + & + & - \\
\hline & & I & - & + & - \\
\hline & 2 & II & - & + & - \\
\hline & & III & - & + & - \\
\hline & & I & - & + & - \\
\hline & 3 & II & - & + & - \\
\hline & & III & aa & aa & aa \\
\hline & & $\mathbf{I}$ & - & + & - \\
\hline & 4 & II & - & + & - \\
\hline & & III & - & + & - \\
\hline
\end{tabular}

Legend: A, B and C = brand; 1, 2, 3 and $4=$ processed unit (package); I, II, III = replication of the package analysis. $+=$ positive result; $-=$ negative result; aa $=$ absence of amplification.

Source: Elaboration of the authors.

Only $45 \%$ of the processed leaves showed Maytenus genus without adulterants. Adulteration with $S$. bonplandii was detected in $38 \%$ of the samples and $17 \%$ of the processed leaves were mixed with another type of plant (fragments with 649 bp in brand A and 690 bp in brand B). Thus,
$55 \%$ of the amplified processed leaves presented some kind of plant adulterant. Tea adulteration with $S$. bonplandii as well as other plants suggests problems during the processing and quality control of Maytenus genus teas. 
Even though there was enough polymorphism to distinguish Maytenus genus and $S$. bonplandii by PCR, 15 restriction endonucleases were utilized in the restriction analysis of the trnH-psbA region of in natura leaves, which results on additional information to distinguish both genera. Among the tested enzymes, MboI, MseI and RsaI were informative, detecting polymorphism in the $\mathrm{trnH}$ $p s b A$ region (Table 3 ).

Table 3. Estimated size (bp) of fragments obtained by digestion with restriction endonucleases of the trnH-psbA intergenic spacer of chloroplast DNA from M. ilicifolia, M. aquifolia and S. bonplandii leaves in natura.

\begin{tabular}{|c|c|c|c|c|}
\hline & \multicolumn{2}{|c|}{ M. aquifolia and $M$. ilicifolia } & \multicolumn{2}{|c|}{ S. bonplandii } \\
\hline Enzyme & Fragments (bp) & Total of fragments (bp) & Fragments (bp) & Total of fragments (bp) \\
\hline Mse I & $256 ; 102$ & 358 & $213 ; 115$ & 328 \\
\hline Mbo I & $350 ; 162$ & 512 & 565 & 565 \\
\hline Rsa I & $375 ; 208 ; 100$ & 683 & 565 & 565 \\
\hline
\end{tabular}

Source: Elaboration of the authors.

MseI produced restriction fragments for Maytenus genus and S. bonplandii. MboI and Rsal generated fragments for Maytenus sp, but they did not recognize restriction sites for $S$. bonplandii (Table 2). Regardless the number of tested enzymes, it was not possible to differ $M$. ilicifolia from $M$. aquifolia. Thus, these enzymes are additional markers for identification of Maytenus genus and S. bonplandii by PCR-RFLP. The amplicons of processed leaves digested with $M b o \mathrm{I}, \mathrm{MseI}$ and RsaI presented results that corroborated the ones found in in natura leaves.

It was concluded that the PCR technique is efficient to distinguish Maytenus sp from S. bonplandii, and detecting the presence of other adulterating plants. However, the PCR-RFLP technique is inefficient to distinguish the species that are very close like $M$. ilicifolia and M. aquifolia. The trnH-psbA spacer of cpDNA is easily amplified and has satisfactory discriminating capacity to authenticate genera of in natura and in processed plants.

\section{Acknowledgements}

The authors thank the Universidade Paranaense (UNIPAR) and Fundação Araucária for the research support and Coordenadoria de Pesquisa e Iniciação
Cientifica (COPIC)/Diretoria Executiva de Gestão da Pesquisa e da Pós-Graduação/UNIPAR for the research grant.

\section{References}

CARLINI, E. A.; BRAZ, S. Efeito protetor do liofilizado obtido do abafo de Maytenus sp (espinheira-santa) contra ulcera gástrica experimental em ratos. In: CARLINI, E. A. (Ed.). Estudo de ação antiúlcera gástrica de plantas brasileiras: Maytenus ilicifolia (espinheira-santa) e outras. Brasília: Central de Medicamentos, 1988. p. 2135.

CHASE, M. W.; COWAN, R. S.; HOLLINGSWORTH, P. M.; VAN DEN BERG, C.; MADRIÑÁN, S.; PETERSEN, G.; SEBERG, O.; JORGSENSEN, T.; CAMERON, K. M.; CARINE, M.; PEDERSEN, N.; HEDDERSON, T. A. J.; CONRAD, F.; SALAZAR, G. A.; RICHARDSON, J. E.; HOLLINGSWORTH, M. L.; BARRACLOUGH, T. G.; KELLY, L.; WILKINSON, M. A proposal for a standardised protocol to barcode all land plants. Taxon, Netherland, v. 56, n. 2, p. 295-299, 2007.

CUÉNOUD, P.; SAVOLAINEN, V.; CHATROU, L. W.; POWELL, M.; GRAYER, R. J.; CHASE, M. W. Molecular phylogenetics of Caryophyllales based on nuclear $18 \mathrm{~s}$ rDNA and plastid $r b c \mathrm{~L}$, atpB, and matK DNA sequences. American Journal of Botany, Baltimore, v. 89 , n. 1, p. 132-144, 2002.

DOYLE, J. J.; DOYLE, J. L. A rapid isolation procedure for small quantities of fresh leaf tissue. Phytochemical Bulletin, Irvine, v. 19, n. 1, p. 11-15, 1987. 
FAZEKAS, A. J.; BURGESS, K. S.; KESANAKURTI, P. R.; GRAHAM, S. W.; NEWMASTER, S. G.; HUSBAND, B. C.; PERCY, D. M.; HAJIBABAEI, M.; BARRET, S. C. H. Multiple multilocus DNA barcodes from the plastid genome discriminate plant species equally well. Plos One, San Francisco, v. 3, n. 7, e2802, 2008.

GONZALEZ, G. G.; PORTELA, T. Y.; STIPP, E. J.; DI STASI, L. C. Antiulcerogenic and anagelsic effets of Maytenus aquifolium, Sorocea bonplandii and Zolernia ilicifolia. Journal of Ethnopharmacology, Ireland, v. 77, n. 1, p. 41-47, 2001.

HOLLINGSWORTH, P. M.; FORREST, L. L.; SPOUGE, J. L.; HAJIBABAEI, M.; RATNASINGHAM, S.; VAN DER BANK, M.; CHASE, M. W.; COWAN, R. S.; ERICKSON, D. L.; FAZEKAS, A. J.; GRAHAM, S. W.; JAMES. K. E.; KIM, K. J.; KRESS, W. J.; SCHNEIDER, H.; VAN ALPHENSTAHL, J.; BARRETT, S. C.; VAN DEN BERG, C.; BOGARIN, D.; BURGESS, K. S.; CAMERON, K. M.; CARINE, M.; CHACÓN, J.; CLARK, A.; CLARKSON, J. J.; CONRAD, F.; DEVEY, D. S.; FORD, C. S.; HEDDERSON, T. A.; HOLLINGSWORTH, M. L.; HUSBAND, B. C.; KELLY, L. J.; KESANAKURTI, P. R.; KIM, J. S.; KIM, Y. D.; LAHAYE, R.; LEE, H. L.; LONG, D. G.; MADRIÑÁN, S.; MAURIN, O.; MEUSNIER, I.; NEWMASTER, S. G.; PARK, C. W.; PERCY, D. M.; PETERSEN, G.; RICHARDSON, J. E.; SALAZAR, G. A.; SAVOLAINEN, V.; SEBERG, O.; WILKINSON, M. J.; YI, D. K.; LITTLE, D. P. A DNA barcode for land plants. Proceeding of National Academy of Sciences of the United States of America, Washington, v. 106, n. 31, p. 12794-12797, 2009.

INFANTE, C.; CRESPO, A.; ZUASTI, E.; PONCE, M.; PÉREZ, L.; FUNES, V.; CATANESE, G.; MANCHADO, M. PCR-based methodology for the authentication of the Atlantic mackerel Scomber scombrus in commercial canned products. Food Research International, Ottawa, v. 39, n. 9, p. 1023-1028, 2006.

JORGE, R. M.; LEITE, J. P. V.; OLIVEIRA, A. B.; TAGLIATI, C. A. Evaluation of anticonceptive, antiinflammatory and antiulcerogenic activities of Maytenus ilicifolia. Journal of Ethnopharmacology, Ireland, v. 94, n. 1, p. 93-100, 2004.

LAHAYE, R.; VAN DER BANK, M.; BOGARIN, D.; WARNER, J.; PUPULIN, F.; GIGOT, G.; MAURIN, O.; DUTHOIT, S.; BARRACLOUGH, T. G.; SAVOLAINEN, V. DNA barcoding the floras of biodiversity hotspots. Proceeding of National Academy of Sciences of the United States of America, Washington, v. 105, n. 8, p. 2923-2928, 2008.
LI, M.; JIANG, R.; HON, P.; CHENG, L.; LI, L.; ZHOU, J.; SHAW, P.; BUT, P. P. Authentication of the anti-tumor herb Baihuasheshecao with bioactive marker compounds and molecular sequences. Food Chemistry, Barking, v. 119, n. 3, p. 1239-1245, 2010.

NGAN, F.; SHAW, P.; BUT, P.; WANG, J. Molecular authentication of Panax species. Phytochemistry, New York, v. 50, n. 5, p. 787-791, 1999.

NODARI, R. O.; GUERRA, M. P. Aspectos genéticos e moleculares da produção vegetal. In: SIMÕES, C. M. O.; SCHENKEL, E. P.; GOSMANN, G.; MELLO, J. C. P.; MENTZ, L. A.; PETROVICK, P. R. (Ed.). Farmacognosia: da planta ao medicamento. Porto Alegre, Florianópolis: UFRGS/UFSC, 1999. p. 25-38.

SONG, J.; YAO, H.; LI, Y.; LI, X.; LIN, Y.; LIU, C.; HAN, J.; XIE, C.; CHEN, S. Authentication of the family Polygonaceae in Chinese pharmacopoeia by DNA barcoding technique. Journal of Ethnopharmacology, Ireland, v. 124, n. 3, p. 434-439, 2009.

UJIHARA, T.; OHTA, R.; HAYASHI, N.; KOHATA, K.; TANAKA, J. Identification of Japanese and Chinese green tea cultivars by using simple sequence repeat markers to encourage proper labeling. Bioscience, Biotechnology and Biochemistry, Tokyo, v. 73, n. 1, p. 15-20, 2009.

UM, J.; CHUNG, H.; KIM, M.; NA, H.; KWON, H.; KIM, J.; LEE, K.; LEE, S.; LIM, J. P.; DO, K.; HWANG, W.; LYU, Y.; AN, N.; KIM, H. Molecular authentication of Panax ginseng species by RAPD analysis and PCRRFLP. Biological and Pharmaceutical Bulletin, Tokyo, v. 24 , n. 8 , p. 872-875, 2001.

VILEGAS, J. H. Y.; LANÇAS, F. M.; WAUTERS, J.; ANGENOT, L. Characterization of adulteration of "espinheira-santa" (Maytenus ilicifolia and M. aquifolia, Celastraceae) hydroalcoholic extracts with Sorocea bonplandii (Moraceae) by high-performance thin layer chromatography. Phytochemical Analysis, Chichester, v. 9, n. 6, p. 263-266, 1998.

ZHAO, Y.; QIU, Y.; GONG, W.; LI, J.; FU, C. Authentication of Actinidia macrosperma using PCRRFLP based on trnK sequences. Botanical Studies, Taipei, v. 48, n. 3, p. 239-242, 2007. 
